\title{
An Introduction to the Vesica Piscis, the Reuleaux Triangle and Related Geometric Constructions in Modern Architecture
}

\author{
Javier Barrallo ${ }^{1}$ (D) Francisco González-Quintial ${ }^{1}$ • \\ Santiago Sánchez-Beitia ${ }^{1}$
}

Published online: 30 May 2015

(C) Kim Williams Books, Turin 2015

\begin{abstract}
The focus of this paper is the Vesica Piscis, a symbol made from the intersection of two circles of the same radius and where the centre of each circle lies on the circumference of the other. The origin of the Vesica Piscis is uncertain, but it can be found in different cultures throughout many historical periods. The Christian religion was most likely responsible for its spread, first as a fish symbol, then as an architectural niche surrounding sculptures and drawings of Christ, and finally as the Gothic pointed arch. A related geometric construction is the Reuleaux Triangle, which uses three intersected circumferences. In the second half of the twentieth century several architects rediscovered both types of geometrical constructions, producing variations of each. This paper commences with an overview of the history and construction of these geometric forms, and then analyses existing buildings which use them, before discussing different design strategies to develop new mathematical models based on ancient designs.
\end{abstract}

Keywords Vesica piscis $\cdot$ Reuleaux triangle $\cdot$ Circle intersection $\cdot$ Structural expressionism

\section{Vesica Piscis}

The Vesica Piscis is a geometric composition formed by the intersection of two circles with the same radius, intersecting in such a way that the centre of each circle lies on the circumference of the other. This geometric form can be expanded to

Javier Barrallo

javier@barrallo.com

1 UPV-EHU, The University of the Basque Country, Universidad del País Vasco, Euskal Herriko

Unibertsitatea, E.T.S. Arquitectura. Plaza Oñati, 2, 20018 Donostia-San Sebastián,

España (Spain) 
construct two contiguous equilateral triangles with opposite orientation in the intersection between the circles. From this it can be easily demonstrated that the relationship between the vertical and horizontal proportions of Vesica Piscis is the square root of three (Fletcher 2004).

Almost every ancient civilization has considered the circle to be a symbol of the infinite or the perfect: it has no vertex, no beginning, and no end. The circle is also related to the sun, the source of life, as well as to many deities. Because of this it is only logical that two circles joined in an intersection are found in a variety of cultural settings. Even without formal knowledge of geometry, the most natural choice of intersection for two circumferences is to join the centres with the perimeters. So it isn't uncommon to come across the Vesica Piscis construction in artefacts from many different cultures.

Because there are no extensive studies in classic mathematics concerning the Vesica Piscis, it is unclear whether there are subtypes, which might include the intersection of circumferences with different radii, or centres that don't coincide exactly with the perimeters. Such cases may be referred to as 'circle-circle intersections', but in this paper we will use the term Vesica Piscis in a more general form, including intersections among ellipses or other curves (Fig. 1).

\section{Etymology and Origin}

'Vesica Piscis' which literally means 'fishes bladder', it is often used in its singular form Vesica Pisces, meaning a fish bladder. The origin of the word is most frequently attributed to religious or mystical sources. But even if there is no agreement about its origin, the term Vesica appears to have been a common way of referring to a vessel or sack produced by animal bladders. Another use of the term was as a crude colloquial name for the vagina, being both a reference to shape and to an earthy or animal odour. In this context, the Vesica Piscis, as the representation of the vagina, would have two socio-cultural interpretations: as an object of desire for men and a feminine symbol of maternity and creation. The association of the Vesica Piscis with female genitals is probably as old as humanity. In many caves with prehistoric art, especially those of northern Spain and southern France, there
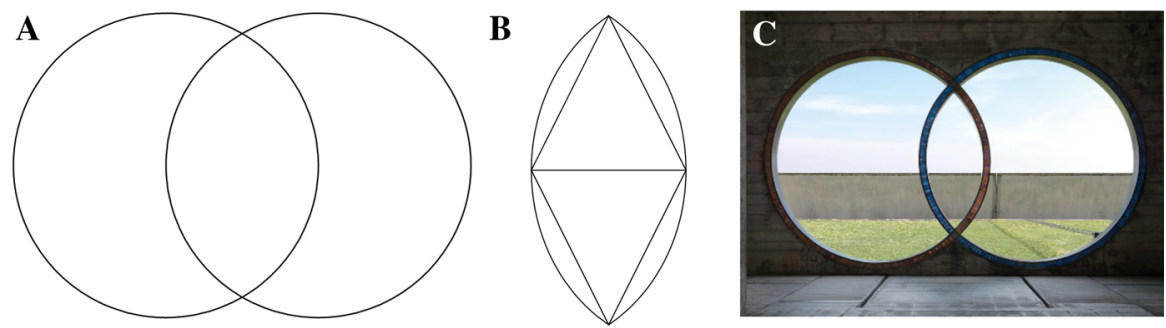

Fig. 1 Vesica Piscis diagram (a); relation of Vesica Piscis with equilateral triangles (b); detail of the Brion Family Cementery by Carlo Scarpa, an example in which the centres of the circumferences do not coincide with the perimeters $(\mathbf{c})$ 
appear Palaeolithic representations of female vulvas. They are shown with many different designs, but their geometric stylization corresponds to the intersection of circumferences (Polledo 2011) (Fig. 2).

During Greco-Roman ages, the Greek goddess of love, Aphrodite, and her Roman equivalent, Venus, had mythological associations with fish. In fact, every Friday in their temples, fish offerings were made for the promotion of sexual vigour and fertility. It should be noted that Aphrodite does not represents the romantic love found in contemporary novels and films, but a passionate love of a strong, sexual nature. The Goddess of love has also been linked to the Pisces constellation by many civilizations, including Greeks, Romans, Phoenicians, Sumerians, Assyrians and Babylonians. Furthermore, two fish swimming in opposite directions, linked by a rope, represents the constellation and this same symbol is evident today as the zodiac symbol Pisces (Michell 2001).

\section{Vesica Piscis in Christianity}

In Christianity, the fish, represented by a Vesica Piscis-like graphic construction, was the symbol of Jesus of Nazareth. Christ's apostles were commonly referred to as fishermen, and Christ and his teachings were represented by the Vesica Piscis symbol with a small addition resembling a fishtail. This addition could have been merely aesthetic or used to indicate a direction as it was used when Christians needed to worship in secret. The symbol was a way for other believers to know where they could worship.

Early Christians would greet each other by raising hands in the shape of a Vesica Piscis. This custom remains today through the hand gesture of prayer, although currently hands remain joined. Other pagan traditions linked to Vesica Piscis have been absorbed and recycled in Christianity. Thus, the Catholic rule of not eating meat on Fridays was an adaptation of the fish offerings to the Greco-Roman Goddesses of love (González 1994).

In early Christianity the Vesica Piscis construction was found in the religious iconography of the ornamental form of Christ's figure. Thus, Vesica Piscis acquired
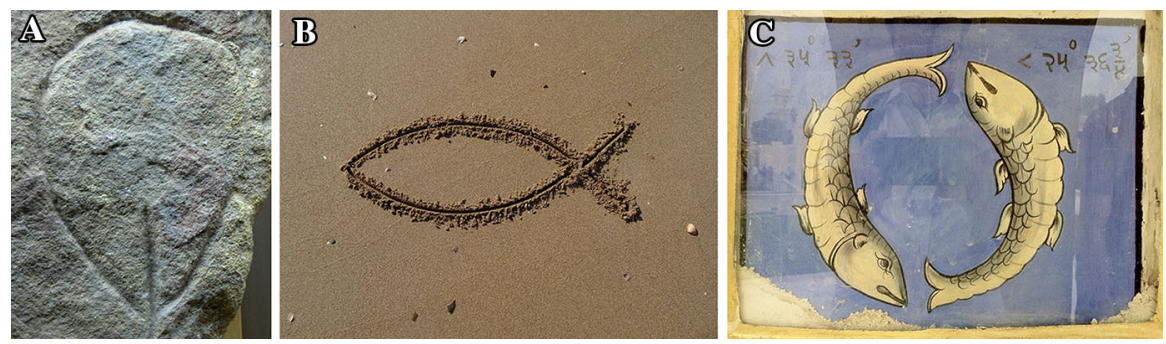

Fig. 2 Prehistoric engraving of a vulva in the Musée des Antiquités Nationales, Saint-Germain-en-Laye (a); Christian symbol based on the fish (b). Piscis zodiac sign in the observatory of Jantan Mantar in Jaipur (c) 
the symbolism of the divine creation, separating it from the ancient pagan customs linked to sexuality and human creation (Fig. 3).

In art and architecture, the Vesica Piscis is usually known as the Mandorla, which in Italian means almond. The mandorla shape is a circle-circle intersection, similar to the Vesica Piscis. It frequently surrounds the figure of the Pantocrator-God or Christ representation-with his right hand raised and the gospel in the left. Pantocrators quickly evolved from painted representations in the apses of the churches to sculptural representations carved in the tympanums of the façades. A hypothesis about the origin of the pointed arch comes from the field of sculpture, where the first masonry masters experimented with the strength the Vesica Piscis construction provided and used it in their arches and vaults.

This is when the Vesica Piscis construction was in its greatest glory. During the Gothic period, many structural and ornamental elements followed a geometry based in circle-circle intersections: arches, windows, vaults, porches and traceries. These distinctive features of gothic cathedrals are based on Vesica Piscis geometry. Although its design appears in every vertical orientation, North-South and EastWest, the Vesica Piscis is never traced over the building's floor (Willis 1843; Williams 2001) (Fig. 4).

After the Gothic period, the pointed arches progressively fell out of fashion. In the Baroque era they practically disappeared, while ellipses and ovals served as successful substitutes. In this period, the Vesica Piscis was removed from the
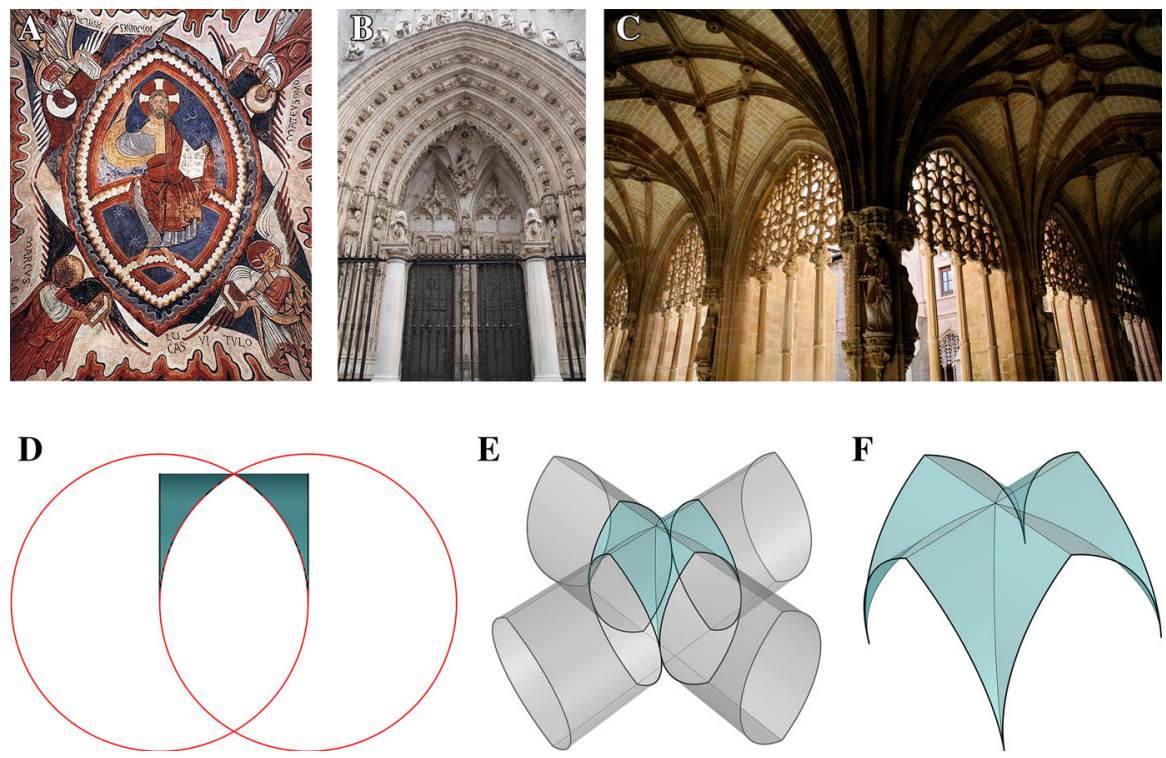

Fig. 3 The Vesica Piscis in Christianity probably moved from paintings like the Pantocrator in Real Colegiata de San Isidoro, León (a) to sculpture like the Porch of the Cathedral of Toledo (b), and then into architecture like the Cloister of the Monasterio de Santa María La Real in Nájera (c). Once developed into the four-sided vault (d), j multiple variations in design and size were developed during the gothic style period 


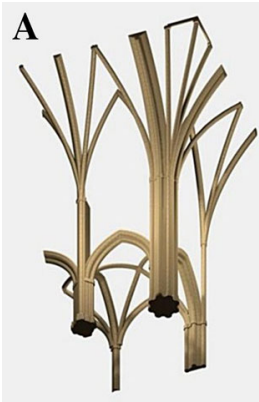

B

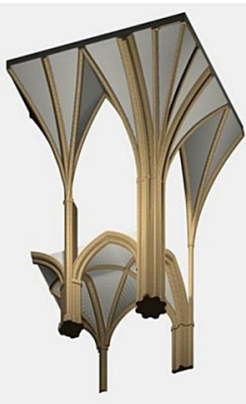

C

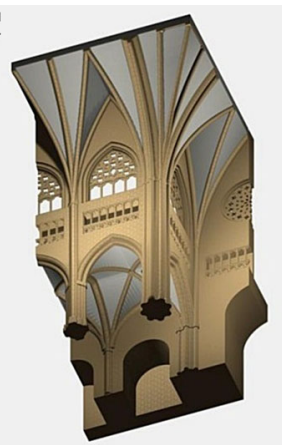

Fig. 4 The Vesica Piscis was the basic design of gothic temples at every stage of construction: arches (a), vaults (b) and walls and tracery (c), as shown in this figure of the Cathedral of Bilbao (fourteenth century)

architectural world. Then the Mannerist architect Sebastiano Serlio (1475-1554), one of the greatest oval construction scholars, employed the Vesica Piscis construction as the starting point of his designs. Additional arches were added to eliminate the vertex of the Vesica Piscis and soften the point of the arch, forming an oval (Huerta 2004).

During the glory days of the gothic revival in the nineteenth century, known as Neo-Gothic, we finally see again the geometry of the Vesica Piscis in constructions, via a clear imitation of medieval architecture, or in the elaborate restorations of ancient gothic buildings.

\section{Vesica Piscis in Modern Architecture}

Surprisingly, the Vesica Piscis, or strictly speaking the circle-circle intersection, appears again at the end of the twentieth century in some famous iconic buildings. In those, formalism and cutting edge design prevail in what we could classify as structural expressionism. Without a doubt, the two most prolific architects using circle-circle intersections in their designs are Norman Foster and Santiago Calatrava. Critically acclaimed, their appeal lies in their spectacular designs used as a symbol of identity. Norman Foster's architecture is more restrained, especially in his later works, which emphasize sustainability and minimal ecological impact. On the other side, Santiago Calatrava's works are excessive in their overemphasis of structure (McQuaid 1993) (Fig. 5).

It is hard to find any practical reason (environmental, structural, sustainable, etc.) in the construction of those fantastic buildings that could justify the presence of the Vesica Piscis. It seems that only its impressive iconic appearance and noticeable character justify its use.

In some cases, a building's identity is cultivated because of the use of the Vesica Piscis. A great example of the symbol's use can be found at the University of Saxion in Enschede, Holland. The striking architecture, designed by the Dutch architect 

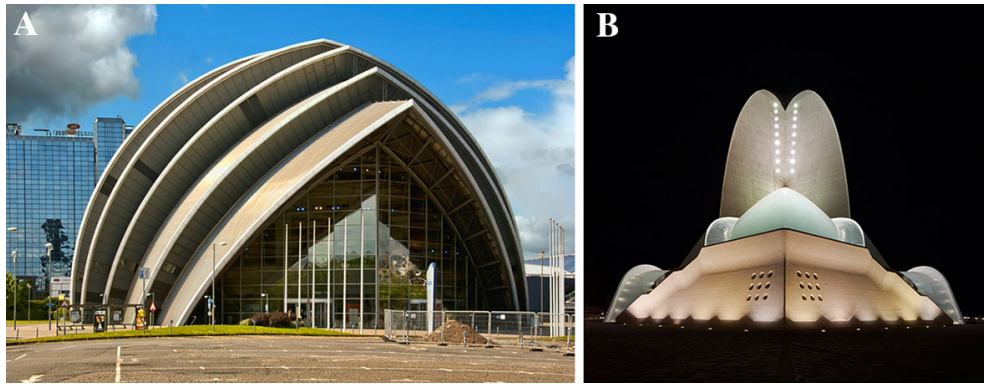

Fig. 5 The Clyde Auditorium, also known as The Armadillo, in Glasgow by Norman Foster (a) and the Auditorio de Tenerife by Santiago Calatrava (b). Both are great examples of the complex structure and spectacular designs developed in modern times using Vesica Piscis geometry

Paul Dirks, is influenced by Vesica Piscis, which appears in six of its pavilions. In addition, even the university logo contains its form (Fig. 6).

A notable exception, a building in which the construction of the Vesica Piscis is justified, is Uruguayan architect Rafael Viñoly's Tokyo International Forum. The slight curvature of the building follows that of the train tracks from Tokyo Station, so the structure is easily recognizable. Viñoly presents an urban solution featuring a huge crystal and steel pavilion whose curved design adjusts perfectly to the rail route, while four other quadrangular buildings are adapted to the urban rectangular layout of the city. The exterior of the principal pavilion shows the shape of an impressive ship floating over the city by means of pronounced curved steel beams (Fig. 7).

\section{Other Examples}

One of the characteristics of buildings based on the Vesica Piscis is a curved form in the floor plan, which is difficult to integrate in the perpendicular layouts of most cities. This geometry is usually reserved for major buildings that have a large area
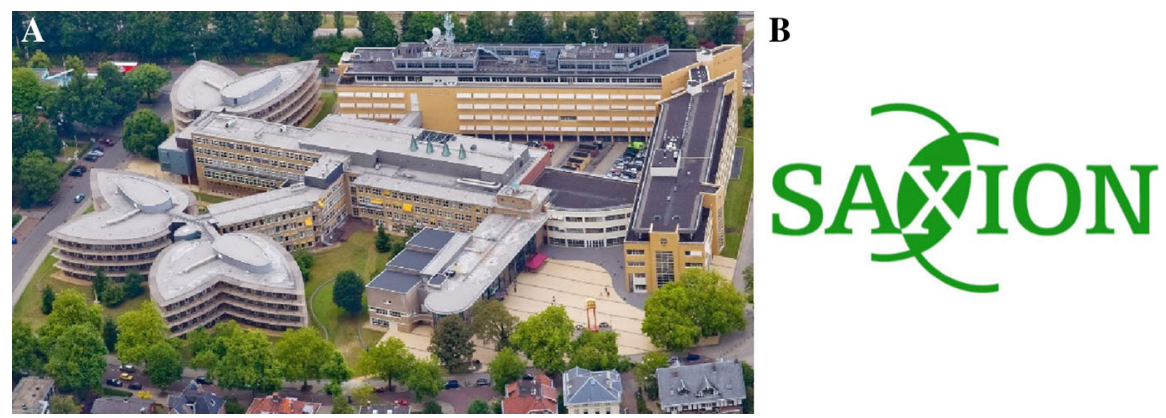

Fig. 6 Both the Saxion University in Enchede designed by Paul Dirks (a) and the Logo of the University (b), are based on the Vesica Piscis design 

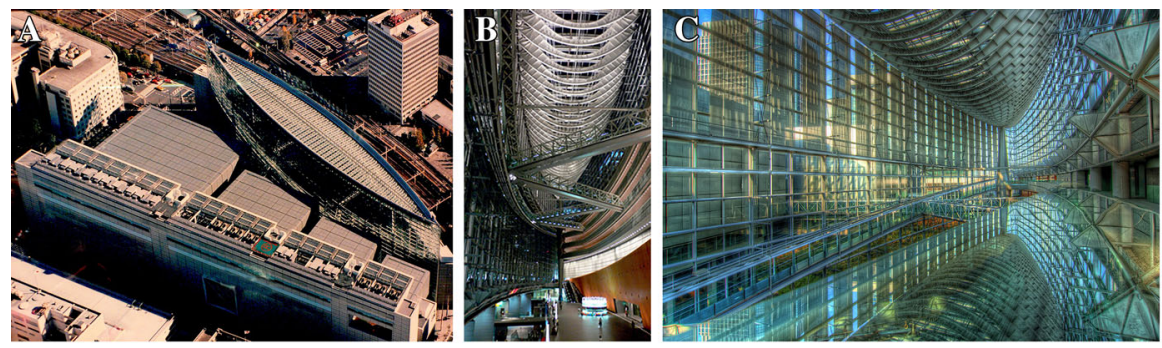

D

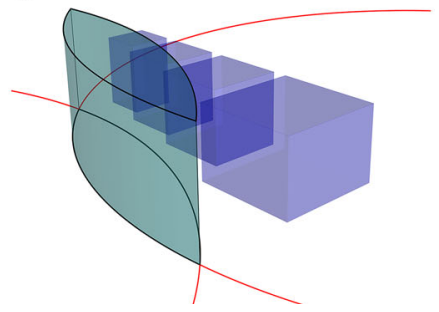

E

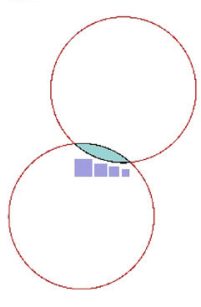

F

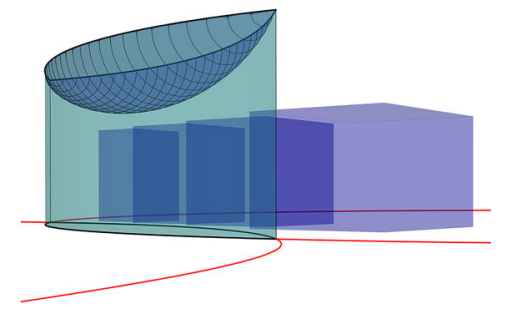

Fig. 7 Tokyo International Forum. The Vesica Piscis main building was designed by architect Rafael Viñoly to be seen like a giant bright boat sailing over the city
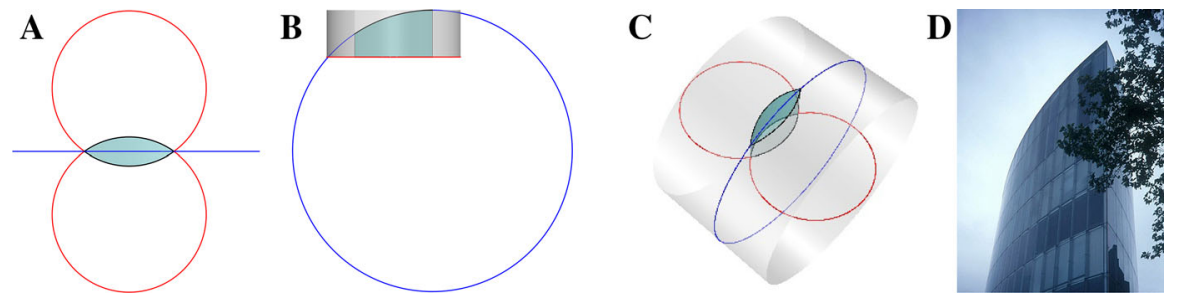

Fig. 8 Business Promotion Centre in Duisburg by Norman Foster. The building is enclosed by three cylindrical sheets in the two façades and the roof

for their construction. To produce a greater impact, the curved line of the floor plan may also be incorporated into the building's elevation.

We can find a simple example of this geometry in the Business Promotion Centre of Duisburg, designed by Norman Foster in 1993, in which the two circumferences that trace the Vesica Piscis construction over the floor of the building are extruded and linked to a third one that determines the curved profile of the elevation. Notice that, when dealing with three-dimensional geometries, we can increase the circumferences to meet the edge of the cylinders, precisely defining the contour of the building's volume (Jodidio 1997) (Fig. 8).

In many of his buildings, the Spanish architect Santiago Calatrava also relates the Vesica Piscis floor plan with the curved line elevation. One of the most beautiful is L'Hemisphèric, constructed in Valencia in 1988. The building is covered by a portion of a sphere, achieving a much more organic effect than Norman Foster's cylindrical cover. 

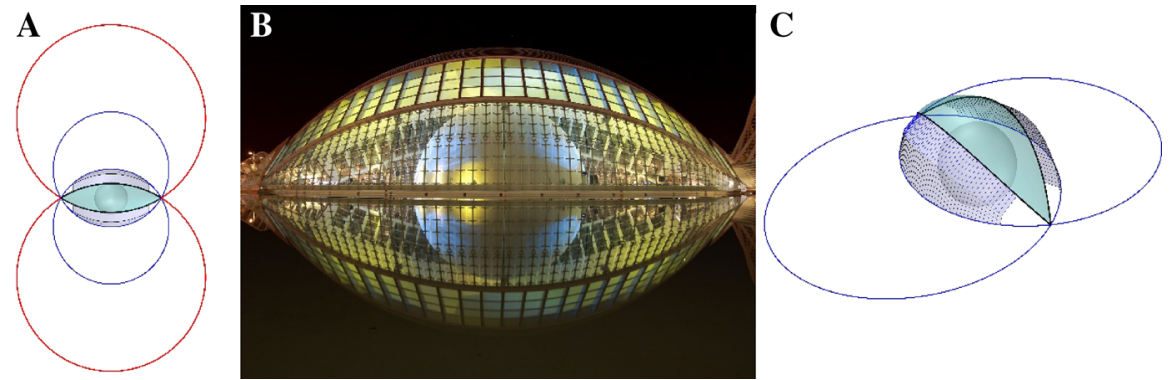

Fig. 9 Santiago Calatrava's L'Hemisphèric in Valencia covered by a sphere and cylinders following a Vesica Piscis scheme, which resembles an eye

Because the sphere cannot completely cover the floor plan traced by Vesica Piscis, the building's volume is laterally closed by two cylinder leafs in each of its two façades. Those sheets are articulated in such a way that allows them to open and close, similar to the movement of an eyelid. A huge spherical IMAX theatre with a 25-m diameter mimics a pupil and dominates the inside of the construction. The combination of these elements provides the building with its characteristic eye shape. The geometry of the Vesica Piscis is observable in L'Hemispheric from various points of view, although the beginning of the sphere from the vertex situated over the floor level lacks the characteristic edge shaped in the form of a ship's prow, which is a strong characteristic of other Vesica Piscis buildings (Fig. 9).

\section{Extreme Vesica Piscis Constructions}

Using the Vesica Piscis construction repeatedly with spheres spread out to the three dimensions, we can create buildings of great complexity. Probably, the most important of this category is the Sydney Opera House, designed by the Danish architect Jørn Utzon in 1957, and inaugurated in 1973. Originally designed to be built for 7 million dollars, the price soon rose to 104 million, which gives an idea of the enormous complexity of the project. The huge roof shells, covered by more than a million tiles of white and cream colours, create a subtle pattern in the form of inverted V's, similar to a reptile's skin.

At first, the shells were designed to be geometrically unrelated, but after various revisions, Utzon decided to use uniform curvature in every direction. Thus the eight spherical sections that define each building could be pulled out of a sphere with a 75-m radius. Each section of the sphere faces another of the same size, creating a cross-section of Vesica Piscis from floor to ceiling. Thus, every shell has identical geometric lecture and structural behaviour, even if they were designed in different heights to satisfy the different auditorium performance necessities (Arup 1969). A smaller and less significant group of shells is found near the entry of the complex (Fig. 10). 


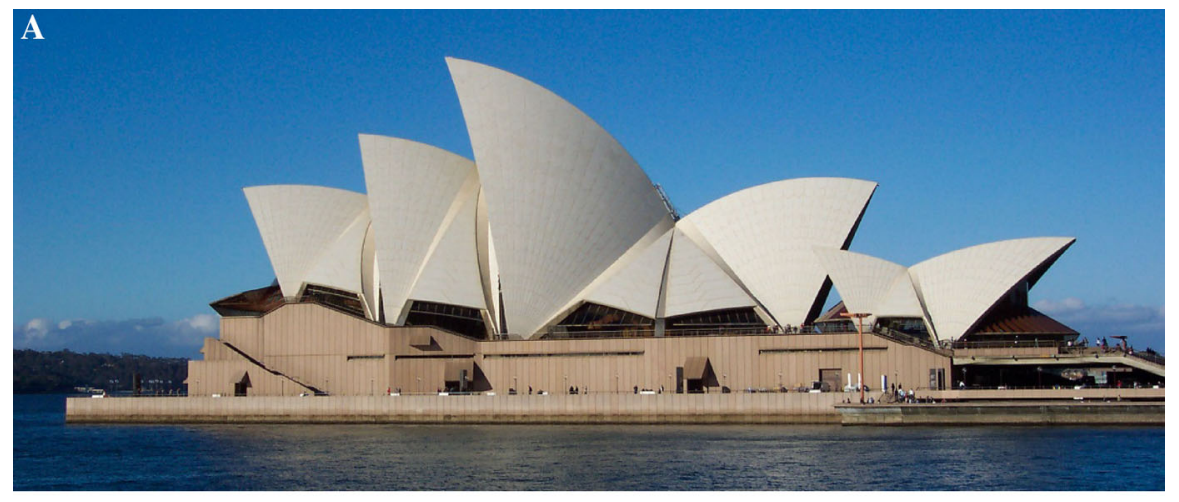

B

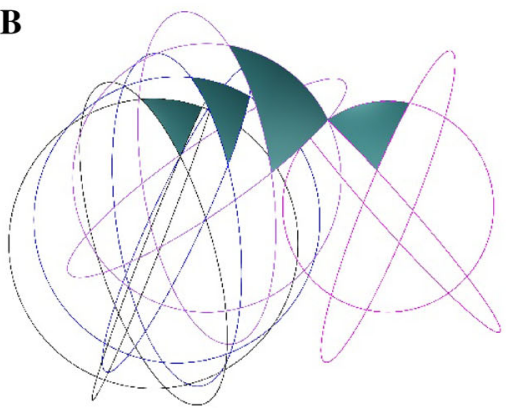

C

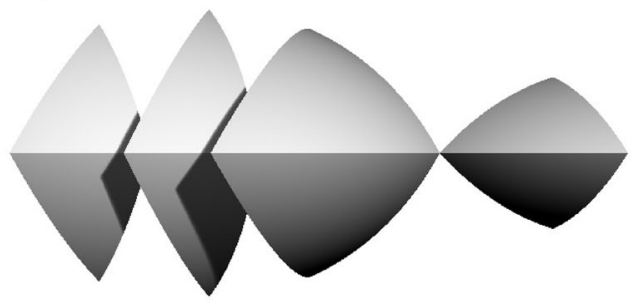

Fig. 10 The iconic Sydney Opera House by Jørn Utzon. All the spherical sections have uniform curvature in all directions, so they can be extracted from a single sphere

Another gorgeous example of the architecture generated through the Vesica Piscis is the Cathedral of Christ the Light, from the Skidmore, Owing and Merrill (S.O.M.) architecture studio, located in Oakland, California. The structure of the cathedral is formed by a hybrid system that houses two semi-spherical wedges made with laminated wood on the inside, and two sections of steel constructed around them.

The sections are based on the construction of the Vesica Piscis through the sphere and cone. The combination of both geometries generates different Vesica Piscis. Thus, both the porch and the apse of the cathedral maintain the construction of the Vesica Piscis, which can also be clearly observed in the cathedral ceiling (Menkin 2012). The futuristic design of the church is accentuated by the perforations that allow light to filter inside, showing us the enormous architectonic potential of circle-circle intersection in contemporary architecture (Fig. 11).

\section{The Reuleaux Triangle}

The Reuleaux triangle can be understood as an extension of the Vesica Piscis through the addition of an arc with the same curvature as the arcs of the original circumferences, so that from the two equilateral triangles that remained enclosed in the original construction, only one is left. The three resulting arcs of the new 


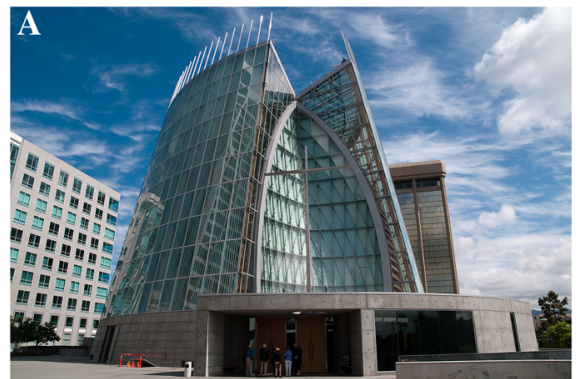

C

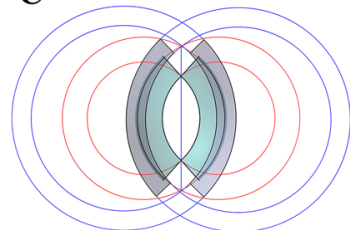

D

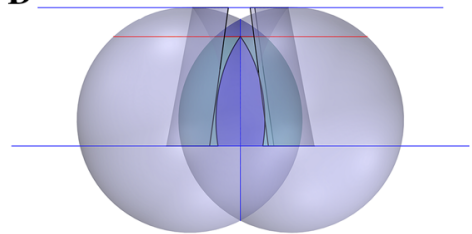

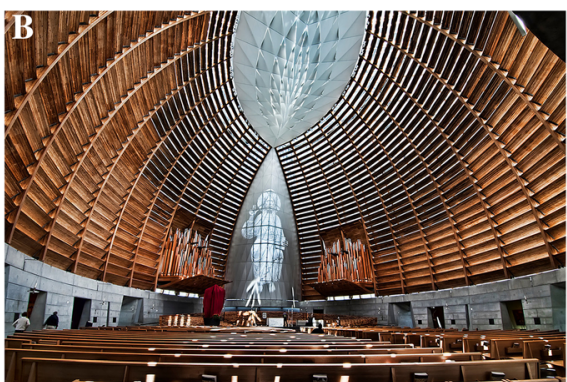

$\mathbf{E}$

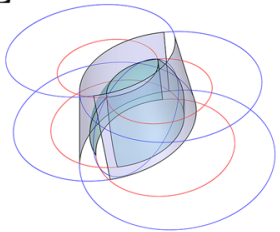

Fig. 11 Cathedral of Christ the Light by S.O.M. in Oakland. It was designed with surfaces from two cones and two spheres cut by several planes
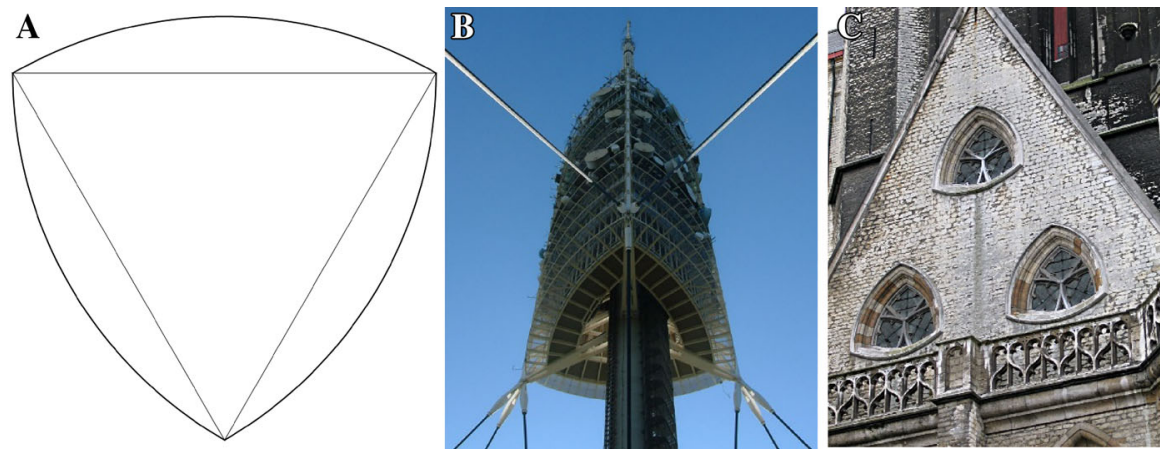

Fig. 12 Reuleaux triangle around an equilateral triangle (a), Torre de Comunicaciones de Collserola in Barcelona by Norman Foster (b), Reuleaux Windows in Sint-Baafskathedraal in Ghent (c)

intersection have the same length and, moreover, the distance from each point of the curve to the opposite vertex is constant. This means it will roll between two fixed parallel lines as would a wheel over a horizontal plane.

The name is due to the German engineer Franz Reuleaux (1829-1905), who designed a whole family of convex polygons with these properties of which the Reuleaux triangle is the simplest example (Moon 2007). It has many remarkable uses in architecture, and interestingly can also be found in furniture elements and even drill bits (Fig. 12).

Apart from the gothic period, where it shared importance with the Vesica Piscis, the Reuleaux triangle also appears in contemporary architecture. One of the first buildings using it is the Kresge Auditorium on the campus of the Massachusetts 

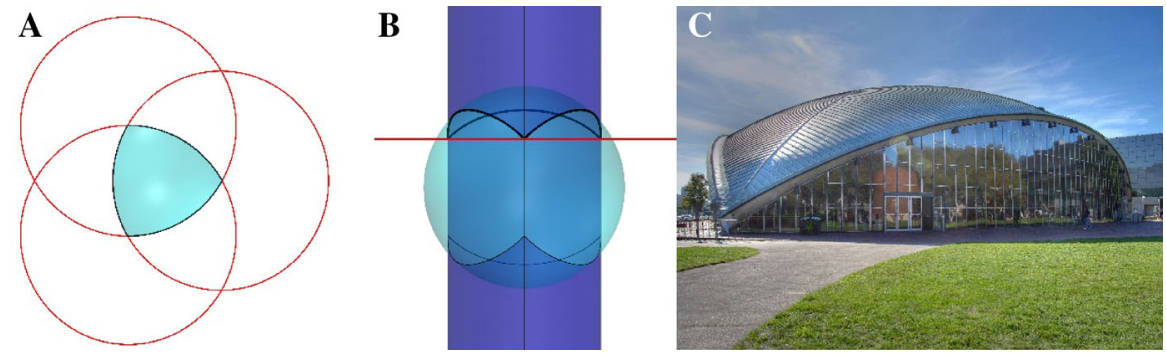

Fig. 13 Kresge Auditorium at the Massachusetts Institute of Technology by Eero Saarinen based on a Reuleaux triangle covered by a sphere

Institute of Technology in Cambridge. Designed in 1955 by Eero Saarinen, the auditorium is defined on the floor by a Reuleaux triangle and then covered by a thin shell structure of reinforced concrete in the form of an eighth of a sphere.

The structure just touches the surface in three points, with no other inside support, giving an unobstructed view from any place in the auditorium. The three cylinders that are extended from the base Reuleaux triangle define the ceiling of the sphere and are also used as a guide for the three crystal curtain walls that give the enclosure three-fold symmetry (Fig. 13).

One of the most recent examples of the use of the Reuleaux triangle in modern architecture is Torre Iberdrola in Bilbao, near Frank Gehry's popular Guggenheim Museum. Constructed in 2012 by the Argentine architect César Pelli, this gorgeous geometric construction emanates from a Reuleaux triangular footprint. A first look at the building gives the appearance that it is a simple extension of the base through three cylinders. But Pelli creates it from three cones, each of which has $1.000 \mathrm{~m}$ height, although the building truncates the structure at $165 \mathrm{~m}$. As one would expect with a conical structure, the cross section of the building diminishes with the height. This can be verified by counting the decreasing number of glass panels found on each rising floor.

It has to be pointed out that in this case the Reauleaux triangle structure does not correspond with the one of an equilateral triangle, but with an isosceles triangle structure. It is therefore a symmetrical building in relation to one axis, not three. But in this way, one edge of the building is emphasized, looking like the prow of a ship that appears to be going out from the Nervión River to the city centre. Pelli leads the eye to the ancient docks of Bilbao which used to occupy those lands (Fig. 14).

\section{Other Variations}

Although we have started this paper with simple geometric constructions, we have been able to show the architectural applications using a wide range of volumetric constructions. There are even more variations: for example, an asymmetric Vesica Piscis, by using different radii to form the circumferences. This is found at the Palacio de Congresos of Valencia, constructed by Norman Foster in 1998. The roof is formed by a smooth cylindrical curve, longitudinally covering the building, giving a soft-warping visual sensation. This is due to the varying levels in the 

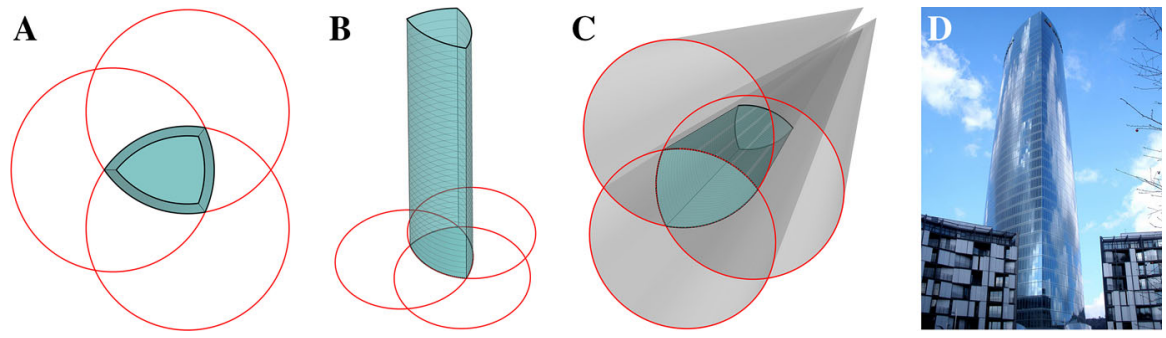

Fig. 14 César Pelli's Torre Iberdrola in Bilbao. The building is designed as the intersection of three cones forming a Reuleaux isosceles triangle
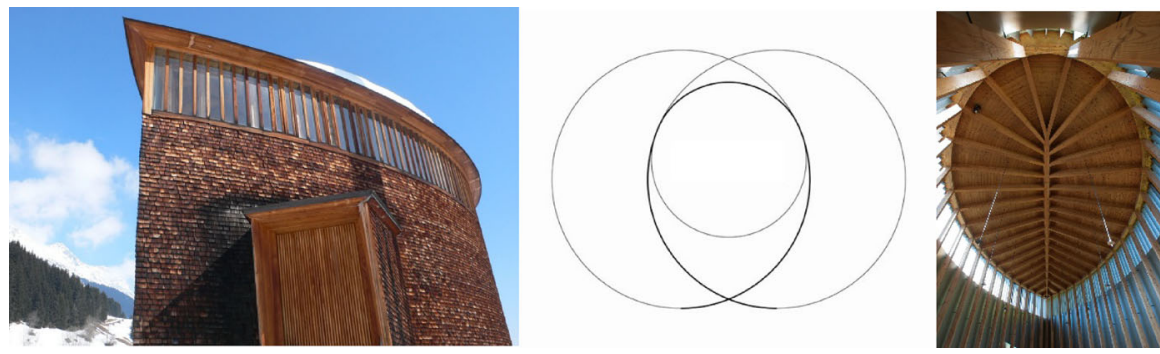

Fig. 15 Saint-Benedict Chapel in Sumvigt, Switzerland, by Peter Zumthor. The floor plan of the chapel corresponds to a hybrid between the Vesica Piscis and the oval

construction-from its highest point, to the vertical edges of the sides of the building, down to the building's widest and lowest level.

Another variation in design that highlights the Vesica Piscis is the Saint Benedict Chapel in Sumvitg, Switzerland, designed by Peter Zumthor. Here, a third arch is introduced over a Vesica Piscis, so that its relation with the other two arches creates continuous curvature. This corresponds with the oval construction technique of Sebastiano Serlio, but in this case it is just applied to one of the sides of the Vesica Piscis (Hart 1996).

In this way, it has produced a curious geometry that looks like the transition between an oval and a cylinder. It is a dynamic geometry, visually surprising, exaggerated by the location of the building over a prominent mountain slope. This is one of the few buildings in which the Vesica Piscis geometry is justified by the surroundings. Due to its location high in the mountains, it is prone to small rock and snow avalanches. Thanks to the prow shape of the chapel formed by the Vesica Piscis, the snow and rock is deflected, minimizing damage to the building. The nave of the church then gradually expands to gain space for the interior (Fig. 15).

\section{Conclusions and Further Experiments}

Starting from an ancient simple composition we have been able to identify the constructive scheme of several famous buildings from modern architecture. The Vesica Piscis may also be extended to a wider range of constructions based on 
circle-circle intersections allowing different radii and positions of the centres. The expansion of these constructions into three dimensions by means of spheres, cones and cylinders results in models with extraordinary architectural presence.

Although Vesica Piscis is most often represented on a large scale in impressive buildings, it is also found in family houses. Two good examples are Casa Luis Figueiredo in Gondomar, Portugal, by Alvaro Siza, and the Robert Llewellyn Wright House in Bethesda, Maryland, by Frank Lloyd Wright. Both houses were designed using concentric and intersecting segments of circles, which produce Vesica Piscis designs of a more modest scale.

The study and design of shapes of architectonic character based on the Vesica Piscis is an interesting task for students of architecture. In addition, the calculation of their areas, distances, or volumes isn't especially complex and is a great exercise in the fields of mathematics and architecture. Other areas of extension include the polygons of Reuleaux of superior degree or modifying the orientation of its arches so that they form a concave object instead of convex. The only limit is the imagination.

\section{Photograph Credits}

The authors wish to acknowledge Francisco Javier Álvarez, Maciej Ratajski, Wojtej Gurak, Chris McAdam, Javier Yaya, Christian Ortiz and Jager Janssen for contributing to this paper with their personal collections, Creative Commons and Wiki Commons.

\section{References}

Arup, Ove and Jack Zunz. 1969. Sydney Opera House. Structural Engineer 47 (3).

Fletcher, Rachel. 2004. Musings on the Vesica Piscis. Nexus Network Journal 6 (2).

González, Justo. 1994. Historia del Cristianismo. Tomo I. Miami: Editorial Unilit.

Hart, V. and P. Hicks, eds. 1996. Sebastiano Serlio on Architecture: Books I-V-Tutte L'Opere D'Architettura et Prospetiva. New Haven: Yale University Press.

Huerta, Santiago. 2004. Arcos, bóvedas y cúpulas. Geometría y equilibrio en el cálculo tradicional de estructuras de fábrica. Madrid: Instituto Juan de Herrera.

Jodidio, Philip. 1997. Foster. Koln: Taschen.

Menkin, Peter. 2012. Visiting the 'New' Catholic Cathedral Christ the Light. London: Church of England Newspaper.

McQuaid, M. 1993. Santiago Calatrava: Structure and Expression. New York: The Museum of Modern Art.

Michell, John. 2001. The Dimensions of Paradise: The Proportions and Symbolic Numbers of Ancient Cosmology. Kempton (Illinois): Adventures Unlimited Press.

Moon, Francis. 2007. The Machines of Leonardo Da Vinci and Franz Reuleaux, Kinematics of Machines from the Renaissance to the 20th Century. Doredrecht: Springer.

Polledo, Miguel. 2011. El Arte Paleolítico de Tito Bustillo. Gijón: Ménsula Ediciones.

Williams, Kim. 2001. The Shape of Divinity. The Mathematical Intelligencer 23 (1).

Willis, Robert. 1843. On the Construction of the Vaults of the Middle Ages. Transactions of the Royal Institute of British Architects 1: 1-69. 
Javier Barrallo earned his Ph.D. in Computer Science at the University of Deusto, Bilbao. He currently belongs to the Department of Applied Mathematics of the UPV-EHU (University of the Basque Country) and teaches in the School of Architecture. He is specialized in the geometry of architecture along with history and the relationship between art and science. He works in the field of structural analysis of heritage buildings and also in the study of complex shapes.

Francisco González-Quintial earned his Ph.D. in Architecture at the University of the Basque Country where he currently teaches in the Department of Architecture at the School of Architecture in the UPVEHU (University of the Basque Country). He is specialized in the geometrical study of buildings and the structural analysis of ancient structures. He also works in the study, design and refinement of complex shapes.

Santiago Sánchez-Beitia earned his Ph.D. in Physics at the University of the Basque Country where he currently teaches in the Department of Applied Physics at the School of Architecture in the UPV-EHU (University of the Basque Country). He is specialized in the structural analysis, restoration and repair of ancient structures. He has developed several techniques for the non-destructive measurement of strains in heritage buildings. 